\title{
From Private to Common: Coevolution of Land-Use Practices and Property Rights
}

In this concluding chapter, we synthesize the results from the previous chapters and discuss how changing land-use regimes among Sami in interior northwest Fennoscandia interrelated with the development of property rights between 1550 and 1780 . The focus is mostly on fishing, hunting, and reindeer grazing, but some other economic activities are also described. During this period, a new tenure system, categorized as reindeer pastoralism, emerged where some users could have hundreds or thousands of reindeer. For households that had amassed large reindeer herds, it became crucial to access both large pastures in the mountains and in the boreal forest to have enough grazing. Eventually, this led to the establishment of common-property regimes in both the mountains and the boreal forest, where grazing became a CPR. For users, the strategy enabled possession of large herds of reindeer on relatively low-yield grazing lands that would otherwise have been impossible. Moreover, the new tenure system required mobility, flexibility, and reciprocity to further optimize the grazing, and to make risks and uncertainties, for example, of weather and grazing conditions, more manageable. At the same time, to assure that everyone's access to resources within the new system was relatively predictable and corresponded to household needs, 
both during the year and from year to year, users had to develop joint strategies to designate enough grazing to individual users, and to mitigate potential conflicts between users. The emergence of this kind of common-property regime is therefore best described as a bottom-up process as it assumes that local users design and implement institutions for common use that all or most users adhere to.

The new governance structure was tightly linked to changes in the users' economy, as many households during that time went from a livelihood based on resources that were considered private, mostly fish and wild game, to a livelihood that was based on CPRs, mostly extensive grazing. Converting from one regime to another was not a quick and uncomplicated leap that all inhabitants made simultaneously. At the same time as more and more households enlarged reindeer herds and needed access to more grazing, many households, especially in the boreal forest, continued to live as before, on fishing and hunting. The governing institutions that emerged had to design tailored property rights for Sami users with different subsistence modes so they could co-exist and access natural resources needed to survive and prosper. Changes in the Sami economy and governance structures were moreover linked to events on a higher institutional level in the surrounding society, such as the introduction of new state tax codes, the government's inauguration of yearly markets in the lappmark, and an increase in Sami population in the first half of the eighteenth century.

\section{Hunting and Fishing to Reindeer Pastoralism}

For most users in Lule lappmark the economy changed profoundly between 1550 and 1780. These changes took place first among users in the mountains and later encompassed many users in the boreal forest. The introduction of a tenure system for keeping reindeer in large herds evoked a focus on grazing resources which came to change the distribution of the Sami villages. To better suit new needs, the villages were eventually reshaped from previously roundish areas, roughly situated either in mountains or boreal forest, to elongated areas that stretched from the northwest mountains to the southeast boreal forest. These new 
villages made it possible for users with reindeer to access both summer and winter grazing within their villages' borders. ${ }^{1}$

In the sixteenth century, hunting still made up the backbone of Sami economy and any surpluses that households accumulated could foremost be attributed to hunting. Before the seventeenth century, as discussed in Chapter 6, hunting had largely been considered a collective enterprise. In fact, it has been suggested that Sami villages came about as a response to the joint organization of hunting. In northern Fennoscandia, the economic importance of hunting peaked around 1570 and thereafter rapidly lost significance as a major income source for most households. Nonetheless, especially small-game hunting continued to be part of the economy in some households, especially among those that stayed in the boreal forest year-round. The boreal forest generally offered more habitats for different wild game species which must have facilitated the perpetuation of hunting. Moreover, wild reindeer seem to have disappeared first from the mountains, which further downplayed the role of hunting there.

As for hunting, the prerequisites for fishing were also more favorable in the boreal forest than in the mountains. Compared to extremely nutrient-poor fishing waters in the mountains, lakes, rivers, and streams in the boreal forest offered both a greater diversity of fish species and larger catches overall. In the seventeenth century, fresh-water fishing was the major food and income source for numerous households in interior northern Fennoscandia. ${ }^{2}$ Albeit, it is more difficult to estimate the role of fishing in preceding centuries. Although fishing probably had been essential for a long time, some evidence indicates that its importance increased and maybe also culminated in the seventeenth century. Tax records from mid-sixteenth century show how particular fishing waters situated west of the lappmark border periodically were used lawfully by coastal peasants from the Gulf of Bothnia. ${ }^{3}$ Later in the sixteenth century, this practice ceased, at least officially, and in the beginning of the seventeenth century, the government began to counteract coastal peasants' fishing

\footnotetext{
1 Vorren (1980).

${ }^{2}$ Norstedt et al. (2014).

3 Göthe (1929, pp. 3-8), Hultblad (1968, p. 38), and Bergman and Ramqvist (2017, p. 11).
} 
in Sami waters. Although we know little about these events and what preceded them, it seems likely that Sami users gained, or regained, access to these waters in the late sixteenth century, and that this speaks to an increased importance of fishing among Sami inhabitants. One hypothesis could be that the waters had not been in demand by Sami users in the early sixteenth century as profitable hunting had taken up more of their time. In sum, fishing and hunting continued to be important for users in the boreal forest throughout the seventeenth century. In 1671, the government tasked a cadastral surveyor and a clerk to map and describe all resources connected to lands belonging to tax-paying Sami in Ume lappmark. ${ }^{4}$ The resulting map and its associated description show that the valued resources on Sami lands predominantly were linked to fishing and hunting.

In the sixteenth century, the majority of households in interior north Fennoscandia had small numbers of tame reindeer to use as decoys in hunts for wild reindeer, and for transportation and milking. The animals also provided furs and meat, but the bulk of these commodities nevertheless came from hunting of wild reindeer. In the early seventeenth century, some households had started to amass more tame reindeer but the number per household was still quite modest, on average. Yet, by then, the number showed a noticeable difference between tax-paying Sami in mountain villages and tax-paying Sami in forest villages. In Lule lappmark, users in Sirkas and Tuorpon had almost twice as many reindeer as users in Sjokksjokk and Jokkmokk - twenty-seven or so to about fourteen, respectively. Later in the seventeenth century, the gap had increased, and herds of hundreds or thousands of reindeer had developed foremost in the mountains. Certain ecological advantages surely augmented the expansion of animal numbers among users with access to grazing in the mountains compared to users whose grazing was restricted to the boreal forest. First, the mountains offered access to relatively nutritious and energy-rich localities for summer grazing, such as open alpine heaths, grasslands, willow thickets, and mountain birch forests that stretched out over enormous areas. ${ }^{5}$ Second, the combination of a normally cold

\footnotetext{
${ }^{4}$ Norstedt (2011) and Norstedt et al. (2014).

5 Skarin et al. (2010).
} 
summer climate with a lot of wind, and a multitude of icy and snowy patches in the mountains, offered the reindeer relief from flying insects, especially oestrid flies. If reindeer cannot escape the flies, they significantly reduce their peaceful grazing and hence their growth. Third, the typically open mountain landscape made gathering the herd less work intensive, compared to the boreal forest, which was an especially advantageous feature when reindeer were being milked every day. Fourth, in the initial phase of reindeer pastoralism, it was probably relatively easy for households with many reindeer to access winter grazing in the boreal forest since most users who lived in the forest year-round had few reindeer and there was thus no or little competition for winter grazing. They might even have welcomed leases for renting out a resource they did not need. Leasing winter grazing could have been a continuation of an older custom that we unfortunately know little about. There were at least two possible options for winter grazing in the preceding tenure system: one was that users moved seasonally with their small reindeer herds to find grazing in the boreal forest, and the other was that they spent winters in the low mountains. Small herds of tame reindeer could probably survive the winter on old vegetation in the mountain birch forests or on ground lichens in windswept higher terrain.

The question of what caused the transition to reindeer pastoralism has been much debated in Sami historical and archaeological research. We adhere to those who argue that trade was a catalyst behind this transformation. Pastoralism implies some sort of economic specialization among users, and pastoralists typically depend on connections with surrounding societies. Pastoralists require contacts with the outside world to sell surplus products and to get food and other commodities they cannot produce themselves. ${ }^{6}$ As users with access to mountain grazing grew their herds, fishing and hunting lost most of their economic importance. Partially, the shift from hunting was a consequence of the extinction of wild reindeer in the mountains, which had been one of the economically most important prey animals for users there. Overall, conditions for fishing and hunting of other game were also considerably less favorable

${ }^{6}$ Khazanov (1994, p. xxxi). 
in the mountains compared to the boreal forest. But even more important was the fact that pastoralists, to become successful, had to engage almost all of their time and energy into the management of livestock, so they had relatively little time for other activities. Fishing and hunting simply became less prioritized.

Pastoralist groups need dependable trading partners. It is therefore not surprising that the expansion of reindeer pastoralism coincided with a growing interest in northern Fennoscandia from adjacent peoples. Gradually, the inhabitants became more tightly linked to different markets in Sweden, Norway, and Russia, not least through the establishment of official trade networks. In Lule lappmark, the Swedish government had taken a more active role in Sami trade starting in the mid-sixteenth century. Nevertheless, reforms, including the establishment of yearly markets in each district of the lappmark in the first decades of the seventeenth century, played a significant role in trade. In 1605, Jokkmokk became the hub for trade in Lule lappmark, and in 1621 the town of Lulea was established on the shore of the Gulf of Bothnia. The government granted some merchants in Luleå unique privileges to trade with the Sami inhabitants in Lule lappmark. The establishment of trade networks with tradespeople in Luleå was probably beneficial for the inhabitants in the lappmark as well, as it secured a steady inflow of sought-after goods, and assured them buyers for the surplus produce they marketed. This trade was based on long-standing traditions through the birkarl system. The inhabitants could also buy and sell products in Norwegian markets in summer and fall, just across the border from Lule lappmark. However, none of these trade networks was a one-way relationship that routinely subordinated Sami producers. Sami inhabitants, especially those with many reindeer, were important trade partners because they produced appraised market goods and they had strong purchasing power. So, reindeer pastoralism became a dominant factor and a prerequisite for trade in this region. A more practical aspect to do with trade is that it requires transportation of goods. Also, in this regard, Sami were the main actors, since they had unique capabilities, including draft reindeer, sleds, and local knowledge, needed to transport goods.

The seventeenth century saw progress in reindeer pastoralism for many users in the mountains at the same time as fishing and hunting became 
more firmly established among many users in the boreal forest. Thus, there were several parallel, ongoing production modes. In several written accounts from the late seventeenth century aimed at describing Sami livelihoods, religion, and customs, the inhabitants were often characterized as either Mountain Sami or Forest Sami, ${ }^{7}$ a dichotomy that has often been repeated and reused in research about Sami cultural history (see Chapter 3). ${ }^{8}$ Here we point to an additional problem related to these concepts. In the late seventeenth century, the economic gap between socalled Mountain Sami and Forest Sami were probably at its largest. As reindeer pastoralism became more widespread in the upcoming century, it also spread to many users in the boreal forest, and by then the two groups began to converge economically. As it turned out, some users in the boreal forest continued to live on fishing and hunting while others amassed large reindeer herds. The differences were, however, strictly economic and not cultural. Inhabitants' cultural affiliation was instead foremost linked to which part of the lappmark they belonged to. So geographical factors, not subsistence mode, seem to have been the deciding factor for language, attires, and customs.

If users were efficient and somewhat fortunate, owning many reindeer could give rise to a substantial surplus that was much more profitable than the gains retrieved from fishing and hunting. The attraction and expansion of reindeer pastoralism in the eighteenth century can perhaps best be understood by the fact that it gave extraordinary incomes that households could spend on utensils and luxury goods, such as silver jewelry, tobacco, and alcohol. Relatively soon, it must have become apparent to everyone that it was possible to become really wealthy as a reindeer pastoralist, and if possible, other inhabitants would not hesitate to follow in the same developmental track. Besides the good profit margin, a tax reform in 1695 also contributed to favorable economic conditions for reindeer pastoralists. The reform stated that the tax level henceforth would be fixed and no longer linked to the taxpayers' assets. In the cadastral book, most tax-paying Sami were connected to a specific

\footnotetext{
7 Several of the authors were commissioned by Johannes Schefferus as groundwork for his book Lapponia.

8 See, for example, Marklund (2015) and Norstedt (2018).
} 
piece of land, but in reality, it was difficult or even impossible for the government to discern exactly how these lands were used, which assets they contained, or even their size. This made individual tax levies arbitrary. So, in 1695, after several attempts to elucidate a more transparent tax levy for individual taxpayers, the government finally abandoned its old strategy and decided on a tax on the Sami village. Thereafter, it became the village's responsibility to deduce each member's tax capacity, collect the tax, and then hand the total levy over to the government's bailiff. Since the tax had been fixed, it did not increase when users amassed more reindeer. The individual levies basically remained unaffected by changes in users' assets, which had not been the case in the old tax system. Nevertheless, in the new tax arrangement, trusted men in the village who were responsible for deducing, collecting, and forwarding the tax had to stay well-informed about each tax-paying member's economic condition. ${ }^{9}$ At the same time, this mandate gave them leverage as a governance institution. With more tax-paying members, the individual user's tax burden would decrease. On the village level, the joint tax became an incentive to use resources as efficiently as possible, and if necessary, redistribute resources to new users, or to returning users. On the other hand, if the number of tax-payers decreased, levies would increase for those remaining. It was rational for the village to strive toward a reasonable resource distribution, so members could have bearable incomes to support their households, and contribute to the village's joint tax. All in all, the mid-eighteenth century was a very successful period for Sami reindeer pastoralists in interior northern Sweden, ${ }^{10}$ which largely became possible through changes in the property regime.

\section{Property Rights}

The expansion of reindeer pastoralism set off complex negotiations among users over common grazing rights. This was a fundamental reorganization of rights in a society that previously had been focused on

\footnotetext{
9 Arell (1977, p. 64).

${ }^{10}$ Kvist (1989, p. 9).
} 
hunting and fishing on mostly private lands. Users who had amassed large reindeer herds needed access to summer grazing in the mountains, winter grazing in the boreal forest, and pathways for migration in spring and fall, each with its own more or less unique ecological requirements.

In the boreal forest, the property-rights regime for hunting and fishing was based on the individual user's right to fish and hunt within a skatteland. In this property regime, fish and game were considered private goods, and it was relatively easy to exclude others from using the resources. Within that skatteland, grazing resources also belonged to the landholder. Originally, these lands had been organized so each provided enough resources for fishing and hunting for households to survive and have a surplus. It had been strategic for users to have control over resources within these large but well-defined territories. However, larger herds required larger, contiguous pastures with larger migration paths to optimize grazing resources seasonally. The new needs did not square with an old land division based on fishing and hunting.

When users expanded their reindeer herds in the seventeenth century, members in the villages in the mountains often had to lease winter grazing from members in villages in the boreal forest. It meant that the former paid a fee for the right to graze their animals on the latter's lands. This kind of leasing arrangement continued into the eighteenth century, but as more and more members in villages in the boreal forest also expanded their reindeer herds, more fundamental changes in user rights became inevitable. In the mountains, the division into individual lands had not been as strict as in the boreal forest, or was completely missing. Therefore, reindeer pastoralism did not impose the same challenges on user rights there as it did in the boreal forest. Regardless, as users in their respective villages needed access to more of each other's grazing land, they started to develop reciprocal arrangements to solve the problem, which eventually led to changes in property rights. This is exemplified by an answer from the local court in Jokkmokk in 1765, when users from Sirkas complained that users from Sjokksjokk were intruding on their grazing. The court argued that the villagers from Sirkas had to tolerate 
trespassing by villagers from Sjokksjokk in spring and summer since Sirkas villagers, in great number, spent winters on lands in Sjokksjokk. ${ }^{11}$

The skatteland was a resource area for households, or kinship groups, mainly for fishing and hunting that could be inherited. ${ }^{12}$ Conflicts around use of these lands that were taken to the local court often involved a few people who lived quite close to each other. For the court, it meant that they often had to determine the boundaries of the skatteland and the user group. ${ }^{13}$ In comparison, conflicts that concerned use of grazing lands often involved extensive areas and many users, sometimes from different villages. To become successful, they needed to build alliances with other users in similar situations, including neighbors. It could also involve strategic marriages, which enabled access to strategic grazing, as well as other benefits from an extended kinship network. Robust social relationships beyond the household became a prerequisite when grazing included both mountain pastures and boreal forests. Hence, the common-property regime that was created required participation from all Sami villages within the court district to work properly.

It is important to acknowledge that throughout the process of creating a new property regime for grazing, users could keep their old individual rights to fishing and hunting. Even though the property regime was contradictory in some regards, it favored users to have private rights to fishing and hunting within well-defined territories and at the same time access to grazing areas far apart; it was possible to combine them within the same property-rights system. Sometimes it required that the rights to different resources were divided among users. If a user had many reindeer, it was possible for him or her to have access only to grazing on a land while another user could have access to fishing waters or hunting grounds. It is striking how rights to resources were renegotiated by local users, and how people's needs often were a guiding principle for the local court. Also, inheritance was a strong right and a land could often belong to the same family or kinship group for several generations, as long as

\footnotetext{
${ }^{11}$ Hultblad (1968, p. 397, evidence 715a) See also Chapter 7.

12 Holmbäck (1922), Kvist (1990, p. 280), and Korpijakko-Labba (1994, p. 53).

13 The boundaries of the resource area and the user group are aligned with Ostrom's design principle 1 (Ostrom 1990, p. 90; Cox et al. 2010).
} 
they had continued to use it. If it was used too little, the court could assign it to another user, or tell the original user to share it with someone who needed it more.

In the boreal forest, fishing and hunting continued to be organized on private lands until the late nineteenth century. ${ }^{14}$ By then, government interventions turned private fishing and hunting rights into collective rights through the Reindeer Grazing Act of 1886. The new common user rights that included grazing, fishing, and hunting were intended for inhabitants who were engaged in reindeer pastoralism, or already had converted to reindeer ranching, and belonged to a newly contrived Sami village. This institution should not, however, be confused with the historical concept of Sami village as we have used it in this book. The Reindeer Grazing Act did not recognize the intrinsic property-rights system that indigenous inhabitants had developed over time. In the early modern era, Sami users had "split property rights," which could include all resources on a piece of land, or rights to resources on a spatial or temporal basis. Eventually, the Swedish government came to favor a decisively more comprehensive property-rights system for Swedish Sami that only included reindeer herders.

Already in the early modern era, the Swedish government had attempted to create uniform legal rules. Conversely, to a large extent, customary and local rules survived and local users retained a strong influence over legal practices. This epoch is best characterized by its great blend of different legal influences. ${ }^{15}$ Regional features of rules persisted, and could be effectively enforced. In Lule lappmark, we have seen how rules regarding hunting, fishing, and reindeer pastoralism were developed by local users who tailored them according to their changing needs.

As discussed in Chapter 2, property systems are usually divided into four basic regimes: state, private, common, and non-property. ${ }^{16}$ In theoretical models, pastoral systems are usually defined as common-property regimes, but many pastoralists have practically no restrictions on access to grazing land, making it similar to a non-property regime. This implies

\footnotetext{
${ }^{14}$ In some areas the use of these lands continued into the twentieth century, foremost in Ume lappmark district.

15 Ågren (1997).

16 Bromley (1991).
} 
that pastoralists have open access to land, which would automatically equate pastoralism with the "tragedy of the commons." 17 However, studies of pastoralists in Africa and Asia suggest that open access in that context does not mean absence of rules, nor leads to depletion of grazing resources. ${ }^{18}$ In the debate about pastoral tenure systems and how well common-property theory can explain those systems, it has been argued that one set of characteristics distinguishes common property from what has been called sovereign pastoral commons: the resource size is small with well-defined boundaries and the ownership group is small with clearly defined membership. ${ }^{19}$ In a pastoral tenure system, areas are extensive with contested boundaries, users are in networks of relationships, and membership is often contested. Hence, an indigenous pastoral tenure system does not fit the "design principles" and is unlikely to be effective common property. Many scholars acknowledge that pastoralist governance systems do not conform to the assumption of mainstream scholarship on common property. ${ }^{20}$ To better categorize the property regimes used, new concepts have been launched to describe pastoralism as an open-property regime ${ }^{21}$ and a complex-mosaic regime. ${ }^{22}$ In the latter, different types of property rights do not need to be allocated on an allor-nothing basis and tenure and property rights form only one type of governance institution. To explain how land-tenure regimes work, one needs to add the social processes and governance mechanisms.

The dichotomy of pastoralism is that livestock holders need secure user rights and spatial and social flexibility due to the often relatively large natural variations in resource access in the landscapes where their animals graze. $^{23}$ Tenure to land was often informal, other rights more secure. Tuareg people who are nomadic pastoralists in Mali, as an example, returned to the same grazing land with their livestock each year. ${ }^{24}$ Even

\footnotetext{
17 Hardin (1968).

18 Moritz (2016) and Robinson (2019).

19 Behnke (2018).

${ }^{20}$ Moritz (2016), Behnke (2018), and Robinson (2019).

21 Moritz (2016).

22 Robinson (2019).

23 Fernández-Giménez (2002, p. 52).

24 Berge (2001).
} 
though they had established a customary right to the land, they had no exclusive right. However, they did have exclusive rights to use man-made wells during the dry season.

How do the property regimes created in Lule lappmark compare to what has been said above? We argue that the property regime to regulate reindeer pastoralism in Lule lappmark during the eighteenth century is best described as a common-property regime. Unlike some other pastoralist systems, it was relatively easy in Lule lappmark to determine the members who shared the resource. Almost all Sami were members of the Sami villages, and each village had representatives in the local court where many conflicts over land use were solved. Even if, in other settings, ${ }^{25}$ huge areas were seen as a problem in the development of common-property regimes, the vast area that Lule lappmark encompassed did not seem to have been a problem in determining rules for the common use of grazing. Like other pastoralists, reindeer pastoralists needed both spatial and social flexibility and secure rights to be able to optimize their resource use. Access to suitable seasonal grazing, both long term and short term, was a strategy that led to more predictability, and thus increased food security for households. Another part of the predictability was the establishment of a governance system wherein users trusted one another, the customary rules, and the local institutions.

\section{Governing}

For a common-property regime to function well, users have to trust the governing institutions at different levels. It is difficult for us today to grasp all the details of the early modern governing infrastructures for natural resources. We assume that most decisions regarding land use were based on deliberations and interactions between users or user groups. Fortunately, preserved court rulings from the early modern local court in the lappmark make it possible to uncover some of the negotiations and arguments that were put forward by users who wanted to defend or claim rights to land or water. These rulings reveal a lot of interesting

25 See, for example, Moritz (2016) and Behnke (2018). 
details about the reality that users operated in, not least around how inhabitants practiced hunting, fishing, or reindeer herding. Nonetheless, some land-use conflicts ended up in court because users wanted the court to settle user rights since the ruling in itself became an official affirmation of the right. It was, for example, common for defendants or plaintiffs to refer to old court rulings during trials as a means to strengthen their own cases. Hence, the local court was an arena where collective-choice rules were made. ${ }^{26}$

For the local court, it was important to uphold and maintain a just and robust local economy. Since most users' livelihoods depended on common-pool resources-fishing waters, hunting grounds, and reindeer grazing land-it was the court's duty to rule in a manner that supported a smooth operation of these activities. To accomplish this, rulings to do with resource use had to be based on a substantial knowledge about both prior and ongoing land use. For the court's head judge, who was appointed by the government and only stayed in the lappmark for a short period of time each year, much of this knowledge must have been inaccessible. Instead, the court relied on trusted indigenous lay-judges from different Sami villages within the court's jurisdiction who possessed vital knowledge for the court to function as intended. Many of the court rulings reveal just how seriously lay-judges or other trusted men took their court assignments, and how meticulously evidence was weighed before they reached a verdict. In especially complicated cases, the procedures often paused for a year between court sessions so the concerned parties and a couple of lay-judges could have time to visit the location of the disputed land or water to gather information and try to resolve the matter on site. Moreover, during the trial, it was common to engage witnesses who could contribute valuable information to help reach as fair a verdict as possible.

The local court in Lule lappmark can be described as a low-cost arena for solving conflicts, which implied that it encouraged users to take conflicts to court. ${ }^{27}$ Since there was only one court session per year, in

\footnotetext{
26 Ostrom (2005, pp. 58-59).

${ }^{27}$ Having a low-cost arena to solve conflicts is part of Ostrom's design principle 6 (Ostrom 1990, p. 90; Cox et al. 2010).
} 
January or February, it did not inflict a particularly large loss of working time for the inhabitants. Furthermore, the yearly court proceedings coincided with market and church services, which enticed a large proportion of the population in Lule lappmark to visit Jokkmokk around that time of year. It was also the time for state tax collection in the seventeenth century, which might not have enticed people to come but was obligatory to participate in.

Sometimes it took several years for the court to resolve a land-use conflict. However, from the court's perspective, it was more important to act credibly or to align deliberations with peoples' perceptions than to come to a quick ruling. ${ }^{28}$ Simply put, in this kind of legal culture, where conflict resolution around land use was based wholly on customary practices, it was indispensable that the inhabitants within a court district be included in and accept the results of the court proceedings. The basic principle behind this legal approach can be expressed in the maxim Quad omnes tangit ab omnibus approbari debet (what touches all must be approved by all), a norm that had been established within medieval law in Sweden. ${ }^{29}$ Obviously, the principle was still applicable in the early modern court in Lule lappmark, at least when it handled collectiveaction problems concerning land use. Like other early modern courts in Europe, another role of the court was to foster good neighborhoods. ${ }^{30}$

The open and transparent handling of court cases during the yearly court sessions conveyed guidelines for individuals and communities with similar problems. In the long run, this learning process surely decreased the number of conflicts that were taken to court. During the open, transparent process, the court clarified the underlying reasonings behind their rulings for all users in the district, lowering the efforts and costs associated with upholding the land-use regime. Due to their concurrence with the yearly market and church services, court sessions were well attended, which increased their impact and made it likely for audiences to give

\footnotetext{
28 J. Larsson (2016, p. 1114).

${ }^{29}$ Korpiola (2014).

30 Rodgers et al. (2011, p. 37) and J. Larsson (2016, p. 1114).
} 
honest reports of what had occurred when they discussed court cases with non-participants.

The jurisdiction of the court coincided, to a large extent, with the inhabitants' resource areas and encompassed both the boreal forest and the mountains. The court district's boundaries followed how its inhabitants migrated or otherwise utilized the landscape. This was particularly true for reindeer pastoralists who needed access to different types of grazing lands depending on the season. Eventually, the entirety of the court district turned into a common-pool regime for grazing, where landuse decisions in one region might impact land use in other regions. By then, the representation of lay-judges from all Sami villages became an even more valued asset since they brought experience of using resources on different landscapes. User groups continued to be rather small, but decisions about how lands and waters should be used, required consideration by more users, and over larger geographical areas than before.

Nonetheless, court districts embraced large areas with relatively few and dispersed users. Even if governance of extensive and coherent grazing pastures was advantageous for reindeer pastoralists, it seems to have been a rather smooth process to divide the court district in Lule lappmark into Jokkmokk in the south and Gällivare in the north in 1751. The relative lack of friction was perhaps due to the fact that the newly established districts were adapted to where inhabitants in the respective districts already utilized land and water. Both districts were elongated and stretched from northwest to southeast, and thus encompassed lands for winter and summer grazing for reindeer pastoralists. One can only imagine what turmoil would have occurred if one court district had covered the boreal forest and the other the mountains. For users, the division into two districts was beneficial for two main reasons: (1) the northern court's sessions were closer to inhabitants around Gällivare, simultaneously with an additional location for winter market, tax collection, and church services in the newly established parish ${ }^{31}$; and (2) the split of the original court district meant that the number of inhabitants

31 Bergling (1964, p. 272). 
in each district remained manageable despite an overall increasing Sami population, thus more court cases, in Lule lappmark. Preservation of small user groups also made it possible to continue the customary judicial principle of transparency and local influence over rulings.

\section{Social Justice}

The transition from an economy based on hunting and fishing to an economy based on reindeer pastoralism created larger social differences between inhabitants in Lule lappmark. The shift increased the gap between rich and poor households. It is likely that fishing and hunting gave more predictable and thus reliable income sources over time, because they were not as exposed to risk as reindeer pastoralism. At the same time, the latter was often much more rewarding given that users were good at managing the herd, and had a certain degree of luck. It explains why many users turned to reindeer pastoralism in the seventeenth and eighteenth centuries, which made it possible for them to influence the development of new property regimes in the region. Reindeer pastoralism yielded many products that gave good incomes, but it also required a lot of work. The herders had to take the reindeer to places where there was rich grazing, protect them against predators, gather and milk the reindeer cows every day, and not least process the milk into cheese. It thus required work efforts by all members of the household and, if possible, by employees. Reindeer pastoralist households often included young men and women from other families who herded and milked reindeer and performed other household chores in return for food, clothes, and reindeer of their own. Even within the pastoralist group, the economic gap between households eventually grew, and some became wealthier than others.

One feature that distinguishes reindeer pastoralists from other pastoralists is its focus on managing only one particular type of livestock. ${ }^{32}$ Most other pastoralists combine herding of several different

\footnotetext{
32 The only exception in Lule lappmark was that a few cows, goats, or sheep were sometimes kept with the herd during summer. See Chapter 8.
} 
livestock, although one species may outnumber the rest and be considered more economically important. ${ }^{33}$ There are several strategic reasons for pastoralists to have different types of livestock; it can, for example, be a way to spread risks since pests or shortages of grazing do not affect all species equally. Also, the capability to regenerate the livestock herd after a crash in numbers can be quicker for some species than others. For example, goats and sheep regain in numbers faster than camels or cows. ${ }^{34}$ Different species can also provide different goods for its owner, and have different grazing strategies that optimize the use of grazing resources. Albeit, reindeer pastoralists had little choice but to rely on only reindeer since no other livestock can survive on grazing during winters in the circumpolar north. But this reliance on just reindeer also put pastoralists in interior northern Sweden at great risk, and contributed to a certain degree of unpredictability in their household economy. As discussed in Chapter 4, this was one argument not to tax Sami in relation to the number of reindeer they owned. The unpredictability was part of the nature of reindeer pastoralism. A deep understanding of a wide range of factors, such as weather, grazing conditions, and reindeer's behavior, were crucial to become successful as a reindeer herder, but even skilled users could have bad luck and loose much of the herd in just a short time.

The property-rights regimes that developed in Lule lappmark also addressed questions about social justice and equity. How much and what kinds of resources should poor users have access to? How should young people, who had not yet established their own household, get access to resources? There were also extremely poor inhabitants in the lappmark who owned practically nothing. They had the option to leave and, for example, go live along the Norwegian coast or at the Gulf of Bothnia in Sweden and live on whatever incomes were available there. ${ }^{35}$ Some of the early modern sources also tell us that "very poor" Sami, unlike the rest of the Sami population at the time, became sedentary by lakes where they survived on fishing and hunting year-round. ${ }^{36}$ In the boreal forest,

\footnotetext{
33 Galaty and Johnson (1990, p. 7).

${ }^{34}$ McCabe (2004, p. 80).

35 Hultblad (1968, p. 39).

36 Öhrling (1970 [1773], p. 11).
} 
the local court could grant underprivileged users the rights to use traps for hunting birds or small game on lands even though the rights holder opposed it. Poor Sami could also spend winters in the mountains where hunting was open access and snare ptarmigans. For young Sami with few resources, an option, if available, was to work in a pastoralist household where they could receive reindeer as payment and eventually amass their own herds.

\section{Final Remarks}

As we have seen, despite the early modern Swedish state's colonial ambitions, local users in interior northwest Fennoscandia developed sophisticated rules for use of natural resources. This was a locally driven process that led to adjusted rules as the economy changed. Users in Lule lappmark managed a complex economy in common, and tailored rights to different resources based on users' demands and needs. When reindeer pastoralism increased in economic importance, lands from the boreal forest into the mountains became managed as one large CPR in regard to which users had both rights and duties. To survive and prosper, reindeer pastoralist households had to migrate with their herds to access different types of grazing depending on the season. By using the local court in Lule lappmark as a collective-choice arena, they could be granted rights to grazing in the mountains, in the boreal forest, and along the migration route. At the same time, the court could consider rights to fish and hunt for other users. In the late eighteenth century, most of this self-governance was lost when the government moved these kinds of decisions to state servants at Länsstyrelsen (the County Administrative Board).

In the nineteenth century, indigenous users who had been proficient at building self-governance institutions through a bottom-up process encountered the Swedish government's top-down view of property rights. The fact that the inhabitants previously had distributed rights to resources dynamically, based on users' customary practices and present needs, was completely overshadowed by the government's legal discourse and view of ownership over land. What undermined the indigenous 
population's positions when it came to determining uses of land and water was the government's interpretative prerogative in the view of what ownership of land meant. Thus, early modern Sami self-governance systems based on customary use for hunting, fishing, and grazing were disregarded and eventually abolished, making it much harder for indigenous users to steer their economies and to co-exist. This was part of an overall development in Sweden in the nineteenth century, when private and state properties were favored and there was little to no understanding of the rationality behind common-property regimes. In these circumstances, it is not surprising that the Swedish government did not recognize a complex property-rights system like the one Sami in Lule lappmark had developed. Sami experienced what many other indigenous people and pastoralists around the world have experienced: that modern nation-states could not and were not willing to see their property-rights systems as functional and rational, or even understand them all.

\section{References}

Ågren, Maria. 1997. Att hävda sin rätt. Synen på jordägande i 1600-talts Sverige, speglad $i$ institutet urminnes hävd. Stockholm: Institutet för rättshistorisk forskning.

Arell, Nils. 1977. Rennomadismen i Torne lappmark: markanvändning under kolonisationsepoken i fr.a. Enontekis socken. PhD dissertation, Umeå, Sweden: Skytteanska samfundet. http://www.diva-portal.org/smash/record. jsf?pid=diva2\%3A616377 $\&$ dswid $=6098$.

Behnke, Roy. 2018. Open access and the sovereign commons. Land Use Policy 78: 708-718. https://doi.org/10.1016/j.landusepol.2018.02.054.

Berge, Gunnvor. 2001. Tuareg notions of space and place in northern Mali. In Politics, property, and production in the West African Sahel, ed. T.A. Benjaminsen and C. Lund, 182-207. Uppsala, Sweden: Nordafrikanska Institutet.

Bergling, Ragnar. 1964. Kyrkstaden i övre Norrland: kyrkliga, merkantila och judiciella funktioner under 1600- och 1700-talen. PhD dissertation, Uppsala University. 
Bergman, Ingela, and Per H. Ramqvist. 2017. Farmer fishermen: Interior lake fishing and inter-cultural and intra-cultural relations among coastal and interior Sámi communities in northern Sweden AD 1200-1600. Acta Borealia 34 (2): 134-158.

Bromley, Daniel W. 1991. Environment and economy, property rights and public policy. Oxford, UK: Blackwell.

Cox, Michael., Gwen Arnold, and Sergio Villamayor Tomás. 2010. A review of design principles for community-based natural resource management. Ecology and Society 15 (4): 38. http://www.ecologyandsociety.org/vol15/iss4/ art38/

Fernández-Giménez, María E. 2002. Spatial and social boundaries and the paradox of pastoral land tenure. Human Ecology 30: 49-78. https://doi.org/ 10.1023/A:1014562913014.

Galaty, John G., and Douglas L. Johnson, eds. 1990. The world of pastoralism: Herding systems in comparative perspective. New York: Guilford Press.

Göthe Gustaf. 1929. Om Umeå lappmarks svenska kolonisation: från mitten av 1500-talet till omkr. 1750. PhD dissertation, Stockholm University.

Hardin, Garrett. 1968. The tragedy of the commons. Science 162: 1243-1248. https://doi.org/10.1126/science.162.3859.1243.

Holmbäck, Åke. 1922. Om lappskattelandsinstitutet och dess historiska utveckling. Stockholm: Statens offentliga utredningar.

Hultblad, Filip. 1968. Övergång från nomadism till agrar bosättning i Jokkmokks socken. PhD dissertation, Uppsala University.

Khazanov, Anatoly M. 1994. Nomads and the outside world, 2 rev. ed. Madison: University of Wisconsin Press.

Korpijaakko-Labba, Kaisa. 1994. Om samernas rättsliga ställning $i$ SverigeFinland. En rättshistorisk utredning av markanvändningsförhållanden och -rättigheter $i$ Västerbottens lappmark före mitten av 1700-talet. Helsinki: Juristförbundets förlag.

Korpiola, Mia. 2014. Not without the consent and goodwill of the common people. The Journal of Legal History 35 (2): 95-119. https://doi.org/10. 1080/01440365.2014.925173.

Kvist, Roger. 1989. Rennomadismens dilemma, det rennomadiska samhällets förändring i Tuorpon och Sirkas, 1760-1860. PhD dissertation, Umeå University.

Kvist, Roger. 1990. Beskattningen av samerna i Sverige 1695-1860. In Älvdal $i$ norr: människor och resurser i Luledalen 1300-1800, ed. Sune Åkerman, Kjell Lundholm, 264-305. Umeå, Sweden: Umeå Studies in the Humanities, Umeå University. 
Larsson, Jesper. 2016. Conflict-resolution mechanisms maintaining an agricultural system: Early modern local courts as an arena for solving collectiveaction problems within Scandinavian Civil Law. International Journal of the Commons 10 (2): 1100-1118. https://doi.org/10.18352/ijc.666.

Marklund, Bertil. 2015. Det milsvida folket. Skogssamernas samhälle i omvandling, 1650-1800. PhD dissertation, Umeå University.

McCabe, J. Terrence. 2004. Cattle Bring us to Our Enemies, Turkana Ecology, Politics, and Raiding in a Disequilibrium System. Ann Arbor: University of Michigan Press.

Moritz, Mark. 2016. Open property regimes. International Journal of the Commons 10: 688-708. https://doi.org/10.18352/ijc.719.

Norstedt, Gudrun. 2011. Lappskattelanden på Geddas karta. Umeå lappmark från 1671 till 1900-talets början. Umeå, Sweden: Thalassa förlag.

Norstedt, Gudrun. 2018. A land of one's own. PhD dissertation, Swedish University of Agricultural Sciences, Umeå. https://pub.epsilon.slu.se/15451/ 1/norstedt_g_180502.pdf.

Norstedt, Gudrun, Anna-Lena Axelsson, and Lars Östlund. 2014. Exploring pre-colonial resource control of individual Sami household. Arctic 67 (2): 223-237. https://doi.org/10.14430/arctic4389.

Öhrling, Samuel. 1970 [1773]. Historisk-ekonomisk avhandling om Arjeplogs församling $i$ Lappland. Arjeplog, Sweden: Silvermuseet.

Ostrom, Elinor. 1990. Governing the commons, the evolution of institutions for collective action. Cambridge, UK: Cambridge University Press.

Ostrom, Elinor. 2005. Understanding institutional diversity. Princeton, NJ: Princeton University Press.

Robinson, Lance W. 2019. Open property and complex mosaics. International Journal of the Commons 13 (1): 804-826. https://doi.org/10.18352/ijc.903.

Rodgers, Christopher P., Eleanor A. Straughton, Angus J. L. Winchester, and Margherita Pieraccini. 2011. Contested common land: Environmental governance past and present. London: Earthscan.

Skarin, Anna, Öje Danell, Roger Bergström, and Jon Moen. 2010. Reindeer movement patterns in alpine summer ranges. Polar Biology 33: 1263-1275. https://doi.org/10.1007/s00300-010-0815-y.

Vorren, Ørnulf. 1980. Samisk bosetning på Nordkalotten, arealdisponering og resursutnytting i historisk-økologisk belysning. In: Nord-skandinaviens historia $i$ tvärvetenskaplig belysning. förhandlingar vid symposium anordnat av Humanistiska fakulteten vid Umeå universitet den 7-9 juni 1978, ed. Evert Baudou and Karl-Hampus Dahlstedt, 235-261. Umeå, Sweden: Almqvist \& Wiksell. 
Open Access This chapter is licensed under the terms of the Creative Commons Attribution 4.0 International License (http://creativecommons.org/ licenses/by/4.0/), which permits use, sharing, adaptation, distribution and reproduction in any medium or format, as long as you give appropriate credit to the original author(s) and the source, provide a link to the Creative Commons license and indicate if changes were made.

The images or other third party material in this chapter are included in the chapter's Creative Commons license, unless indicated otherwise in a credit line to the material. If material is not included in the chapter's Creative Commons license and your intended use is not permitted by statutory regulation or exceeds the permitted use, you will need to obtain permission directly from the copyright holder.

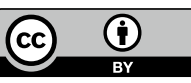

